\title{
FIBER TO THE HOME (FTTH) AND COMPETITION: DEVELOPMENTS IN THE NETHERLANDS \& CANADA
}




\section{Context}

口 FTTH as the "final broadband service" due to high speeds?

$\square$ Japan \& Korea: $>40 \%$ of residential broadband connections

Europe $<1 \%$, U.S. 3\% 


\section{Many questions \& uncertainties}

$\square$ High upfront investments

$\square$ Technological superiority?

$\square$ Replacement of other last mile infrastructures?

$\rightarrow$ Should FTTH be regulated?

$\square$ Incentives for investor to recoup investment

$\square$ Stimulate competition

- If open access (service based competition): Opening at certain conditions

$\square$ Relation to technology?

a PON vs. PtP

- Costs, complexity of enabling open access, sharing of fiber between subscribers 


\section{Questions}

1. How is FTTH changing the competitive landscape of broadband markets?

2. What factors underlie the growth of FTTH networks? 


\section{Developments in the Netherlands}

$\square$ Early 2009: 4\% of broadband connections are FTTH

$\square$ Projections: $>70-80 \%$ FTTH coverage by $2020-2030$

Currently:

$\square 349.000$ homes passed

$\square 62 \%$ ready for service

$\square 139.000$ active subscribers

$\square 61$ ongoing FTTH projects (in different areas) 


\section{The three layered access model}

\section{Regulatory Requirements}

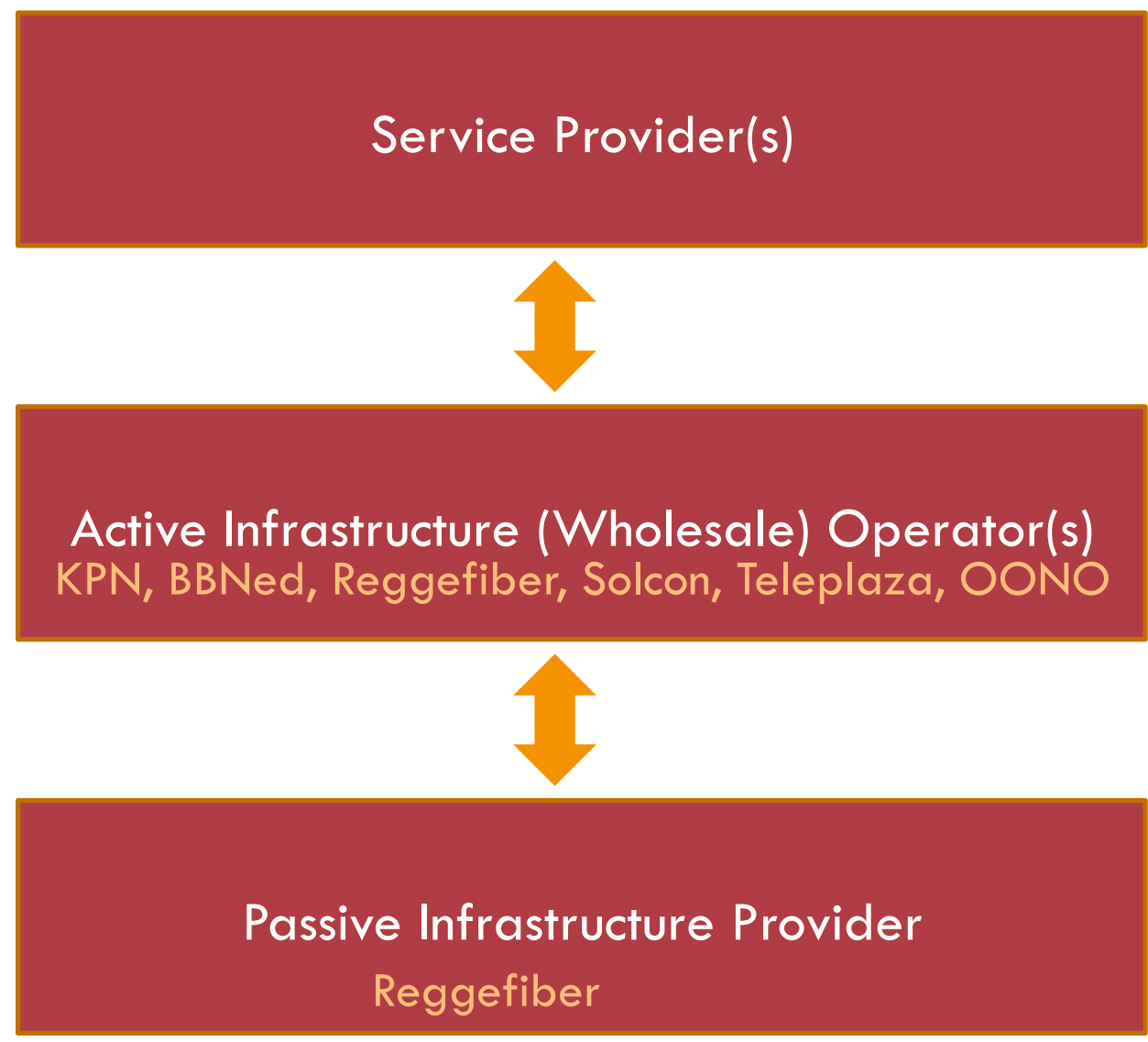

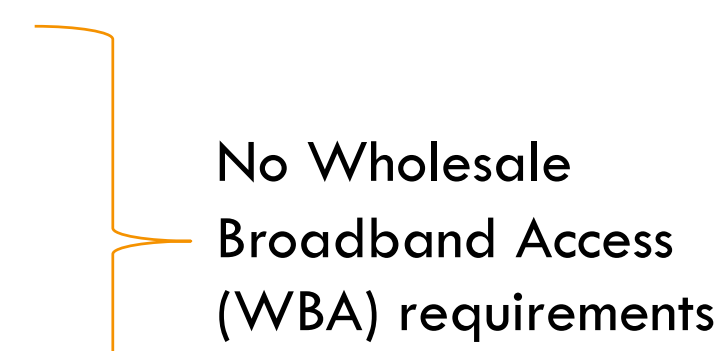

Reggefiber is regulated: Unbundling 


\section{Amsterdam Citynet}

$\square$ Problems with the 3-layered model:

$\square$ Who is responsible for marketing to end-users?

$\square$ Experience: Pure service provision is not highly desired; entrants want to act as active operators

$\square$ Result: Exclusivity period - couple active operator and service provider together

- @Amsterdam Citynet all major CLECs expected to collocate 


\section{New Market Entrants}

$\square$ Teleplaza (Intermezzo, Tilburg)

- Active operator in Tilburg; passive provider in few projects

口 Provides Internet access services, resells Ziggo's RTV services

$\square$ OONO (Red Apple, Rotterdam)

a $1^{\text {st }}$ GPON network in NL

$\square$ Active operator

- Claims first structurally separated network

- 3 different providers for Internet, telephony \& TV

- Wireless Campus acts as service broker

- Lease tariff: $€ 0$, subscribers get discount on triple play services

$\square$ Both no interest in Reggefiber's networks 


\section{Effects: Infrastructure Competition}

$\square$ Cable providers sticking with cable \& upgrading

口 DOCSIS 3.0

- UPC in Amsterdam to offer 120 Mbps service (Fiber Power broadband service), Ziggo is advertising to follow

- Heavy advertising, including localized

$\square$ The future of FTTC/VDSL?

$\square$ Incumbent KPN not very active anymore?

$\square$ Tele2 to start offering VDSL2 from CO, under the name Fiberspeed 


\section{‘Conclusion’ NL}

- Even though extent of service based competition remains unclear,

$\square$ Market growth stimulated by:

- Proactive regulator with regulation that requires unbundling

- Competitive market in general $\rightarrow$ facilities based competition

- Investment not so much by telcos but municipalities, social housing agencies, etc. 


\section{A Different Story: Canada}

$\square 0 \%$ footprint

$\square$ Mostly very small, rural, projects

$\square$ Unregulated

$\square$ Mostly use of GPON architecture, one project with dark fiber

$\square$ Problems:

Backhaul

$\square$ Finding a service provider

$\square$ Investment 


\section{‘Conclusion’ Canada}

口 Growth impeded by:

- Limited competition in the market -> oligopoly leads to limited activity by incumbents, independents afraid to invest for fear of bankruptcy

- Small providers having difficulty obtaining funds

- Problems with backhaul (FTTH = very high speed? Nope -5 Mbps) 


\section{Summary \& Conclusion}

$\square$ Prospects for service based competition remain questionable

$\square$ At what level will competition take place?

$\square$ FTTH to stimulate infrastructure competition in competitive markets

$\square$ So what about markets where competition is limited?

$\square$ Regulatory priority: stimulate investment

$\square$ Clear direction by the regulator is needed: with uncertainties no investments 


\section{Questions?}

